\title{
High leptin in pregnant mink (Mustela vison) may exert anorexigenic effects: a permissive factor for rapid increase in food intake during lactation
}

\author{
Anne-Helene Tauson ${ }^{1 *}$, Mats Forsberg ${ }^{2}$ and André Chwalibog ${ }^{1}$ \\ ${ }^{1}$ Department of Animal Science and Animal Health, The Royal Veterinary and Agricultural University, \\ Bülowsvej 13, DK-1870 Frederiksberg C, Denmark \\ ${ }^{2}$ Centre for Reproductive Biology in Uppsala, Department of Clinical Chemistry, Swedish University of Agricultural \\ Sciences, Box 7038, S-750 07 Uppsala, Sweden
}

(Received 15 June 2003 - Revised 9 October 2003 - Accepted 23 October 2003)

\begin{abstract}
The role for leptin in food intake regulation in the mink, a polytocous seasonal breeder with altricial young, was investigated in pregnant and lactating dams and data were related to quantitative energy metabolism measurements and plasma concentrations of other important metabolic hormones. A total of nine mink dams were measured in consecutive 1-week balance periods, each including a $22 \mathrm{~h}$ measurement of heat production by means of indirect calorimetry, and blood was sampled at weekly intervals throughout gestation and during lactation weeks 1-4. Intake of metabolisable energy (ME) was high and energy balance was positive until the first third of true gestation. During mid- and late gestation ME intake decreased $(P<0.001)$ while heat production remained almost constant, resulting in negative energy balance and the loss of body weight. From late gestation until lactation week 4, ME intake increased by 3.5 times, but weight loss continued. Plasma concentrations of leptin were approximately doubled during the last two-thirds of true gestation $(P<0 \cdot 01)$, demonstrating a clear gestational hyperleptinaemia. Concentrations declined rapidly after parturition and then remained stable. Insulin was independent of leptin, with low concentrations coincident with hyperleptinaemia. Also, concentrations of thyroid hormones declined during gestation, probably reflecting the low food intake. Hyperleptinaemia concomitant with low ME intake, negative energy balance and mobilisation of body reserves suggested an anorexigenic effect of leptin in pregnant mink. This suppression of food intake in late gestation might be permissive for the rapid increase in food intake occurring after parturition.
\end{abstract}

Energy metabolism: Substrate oxidation: Thyroid hormones: Insulin: Insulin-like growth factor-1

Various strategies are applied among species for securing a maximum reproductive outcome. For seasonal breeders the situation is complicated by the necessity to survive a period with a scarcity of food and still maintain sufficient body reserves to support reproduction. The mink (Mustela vison) is a polytocous seasonal breeder with one annual breeding season in March in the Northern hemisphere. Similar to other seasonal breeders, it has annual cycles of changes in food intake and body weight (Hansen et al. 1991), body weights decreasing by $10-15 \%$ during the winter months in ad libitum-fed dams (Korhonen \& Niemälä, 1998). The breeding mink therefore faces the problem of conceiving after a period of declining body reserves. Furthermore, the reproductive performance of mink is highly responsive to energy supply, especially in yearling females (Tauson, 1993), so the pregnant dam may have to support growth and viability of a large number of fetuses. The dam gives birth to altricial young after a gestation comprising a short embryonic diapause and then a true gestation period of $31 \mathrm{~d}$ (Murphy \& Douglas, 1992).

The role of leptin in the regulation of food intake, body weight and energy homeostasis has, since its discovery (Zhang et al. 1994), gained increasing recognition (for reviews, see Baile et al. 2000; Havel, 2000; Schwartz et al. 2000; Frübeck, 2001). A role for leptin in the regulation of reproduction (for a review, see Cunningham et al. 1999) has been proposed.

It has been suggested that the regulation of leptin in pregnancy probably is an outcome of cross-talk between the placenta, fetus and maternal adipose tissue (Henson \& Castracane, 2000), and that it is involved in the control of maternal nutrient availability and fetal energy homeostasis. It may even cause the predetermination of a body

Abbreviations: BEFIMP, before implantation; CHO, carbohydrate; $\mathrm{FT}_{4}$, free thyroxine; GEST1/3, first third of true gestation; GEST2/3, second third of true gestation; GEST3/3, last third of true gestation; HE, heat production; IGF-1, insulin-like growth factor-1; IMP, about the time of implantation; LACTW1, first week of lactation; LACTW2, second week of lactation; LACTW3, third week of lactation; LACTW4, fourth week of lactation; LW, live weight; ME, metabolisable energy; OXCHO, quantitative oxidation of $\mathrm{CHO}$; OXF, quantitative oxidation of fat; OXP, quantitative oxidation of protein; $\mathrm{RN}$, retained $\mathrm{N} ; \mathrm{T}_{3}$, triiodothyronine; $\mathrm{TT}_{3}$, total triiodothyronine; $\mathrm{T}_{4}$, thyroxine; $\mathrm{TT}_{4}$, total thyroxine; $\mathrm{UN}_{\text {, urinary }} \mathrm{N}$.

* Corresponding author: Dr Anne-Helene Tauson, fax + 45352830 20, email aht@kvl.dk 
weight set point imprint to be carried forward postnatally (Frübeck, 2001). Leptin may be an important growth factor for the fetus, or it may signal energy status between mother and fetus (Caprio et al. 2001; Mostyn et al. 2001).

Lactation is usually more energy demanding than gestation, especially in polytocous species. In cases when food supply alone cannot meet energy requirements, body energy reserves will be mobilised for milk production. The balance between food intake and body condition during gestation and food intake and performance during lactation is therefore of paramount importance for both the pregnant or lactating dam and her offspring. After parturition plasma concentrations of leptin decline, and it has been suggested that low leptin concentrations contribute to stimulate food intake and milk production (Brogan et al. 1999; Woodside et al. 2000) and possibly also cause lactational anoestrous (Woodside et al. 2000; Caprio et al. 2001).

The pregnant mink usually exhibits a low food intake during the part of gestation when fetal growth is rapid. This results in negative energy balance in late gestation (Tauson et al. 1994), and after parturition the body must adapt to producing a high milk output (Fink et al. 2001) in order to support the rapid weight gain of which mink kits are capable (Tauson, 1994).

The mink dam selected for high litter size and with a high milk yield could therefore serve as a suitable model for studies of the energetic demands on high-producing polytocous species and how they are able to sustain production performance by balancing intake of food with mobilisation of body reserves. The objective of the present study was therefore to investigate the quantitative energy and protein metabolism of pregnant and lactating mink dams and the hormonal regulation of these processes, with special emphasis on the role of leptin in the regulation of food intake and energy balance.

\section{Materials and methods}

\section{Animals, housing and management}

A total of nine 2-year-old mink dams of the standard brown genotype (Nes et al. 1987) were used. The animals were raised and bred at the experimental farm of the Royal Veterinary and Agricultural University. The dams were mated to non-experimental males on two consecutive days, starting on 17 March. The dams were then transferred to the laboratory, where they were kept in metabolism cages (for a description, see Jørgensen \& Glem-Hansen, 1973) equipped with devices for quantitative collection of feed residues and excreta and for measuring water intake. Before expected parturition nest-boxes were put into the cages, and a bottom screen with finer meshes $(6.4 \times 25.4 \mathrm{~mm})$ was used. When the animals gave birth, the date and number of live and stillborn kits were recorded and the kits were weighed. Kits born during the daytime were weighed as soon as parturition was considered to be completed, and kits born during the night were weighed the following morning. Some cross-fostering took place; two dams giving birth to two and three kits were given kits so that they suckled litters of five, and from one dam giving birth to ten kits three were removed. The animals were kept under natural daylight conditions (end of March until end of May; $55^{\circ} \mathrm{N}, 16^{\circ} \mathrm{E}$ ). After a 1week adaptation period, the experiment was carried out in consecutive 1-week balance periods, each including a $22 \mathrm{~h}$ respiration experiment by means of indirect calorimetry. The experiment lasted from shortly after breeding until approximately 4 weeks after parturition. The experiment ended before the kits started to consume significant amounts of other food than their mothers' milk.

\section{Ethical approval}

The experimental procedures followed Danish National Legislation and the guidelines approved by the member States of the Council of Europe for the protection of vertebrate animals (Anonymous, 1986).

\section{Diets and feeding}

Throughout the experiment the animals were given free access to food, i.e. the daily feed allowances were adjusted so that there were some food residues. Conventional wet mink diets purchased from a commercial mink food producer (Stårup Fodercentral, Højby, Sjælland, Denmark) were used. From the start of the experiment (end of March) until parturitions started (late April) a gestation-period diet was used, and from then on until the end of the experiment a lactation-period diet was fed. The diets were purchased on single occasions, weighed into plastic bags containing daily portions, and then immediately frozen. The food was taken out of the freezer the day before use and was thawed overnight. The dietary composition, the analysed chemical composition of the diets and the calculated percentages of metabolisable energy (ME) derived from protein, fat and carbohydrates $(\mathrm{CHO})$ are reported in Table 1.

\section{Balance and respiration experiments}

The quantitative collection of food residues and excreta was carried out once daily between 08.30 and 12.00 hours, and the total amount from each period was stored at $-18^{\circ} \mathrm{C}$ until analysis. Urine was collected in bottles containing $10 \%(\mathrm{w} / \mathrm{v}) \mathrm{H}_{2} \mathrm{SO}_{4}(5 \mathrm{ml})$. The screen for faeces collection and the urine collection funnel were rinsed with anhydrous citric acid $(10 \mathrm{~g} / \mathrm{l})$ at the end of the daily collection procedure.

Each balance period included a $22 \mathrm{~h}$ respiration experiment by means of indirect calorimetry in an open-air circulation system. The respiration chamber (760 litres) was designed so as to permit the direct insertion of the metabolism cage into the chamber. The animals were moved to the respiration chamber at least $1 \mathrm{~h}$ before the start of the experiment to adapt to the surroundings. The temperature and relative humidity were kept at 15 to $18^{\circ} \mathrm{C}$ and 0.65 to 0.75 , respectively. Air from the chambers was analysed every third min for concentration of $\mathrm{O}_{2}$ and $\mathrm{CO}_{2} \cdot \mathrm{O}_{2}$ was analysed by a paramagnetic analyser (Magnos 4G; Hartmann \& Braun AG, Frankfurt, Germany), and $\mathrm{CO}_{2}$ was analysed with the IR principle (Uras 3; Hartmann \& Braun AG). 
Table 1. Dietary composition and analysed chemical composition $(\mathrm{g} / \mathrm{kg})$ of the gestation- and lactation-period diets

\begin{tabular}{|c|c|c|}
\hline & Gestation period & Lactation period \\
\hline Fish offal & 450 & 390 \\
\hline Industrial fish & 250 & 300 \\
\hline Poultry wastes & 110 & 75 \\
\hline $\mathrm{Hb}$ & 50 & 60 \\
\hline Barley & 30 & 60 \\
\hline Wheatbran & 30 & 20 \\
\hline Fish-meal + maize gluten meal & 15 & 15 \\
\hline Wheatgerm & 7.5 & - \\
\hline Soya fibre & 7.5 & 15 \\
\hline Soya oil & $5 \cdot 0$ & 20 \\
\hline Vitamin and mineral mixture* & 2.5 & 2.5 \\
\hline Water & to make 1000 & to make 1000 \\
\hline \multicolumn{3}{|l|}{ Analysed chemical composition } \\
\hline DM & $326 \cdot 4$ & $319 \cdot 3$ \\
\hline Ash & $31 \cdot 2$ & 35.9 \\
\hline Crude protein & $170 \cdot 0$ & $158 \cdot 8$ \\
\hline Fat & 47.5 & $48 \cdot 6$ \\
\hline Carbohydrate & $77 \cdot 7$ & $76 \cdot 1$ \\
\hline Gross energy (MJ/kg DM) & $22 \cdot 8$ & $22 \cdot 1$ \\
\hline \multicolumn{3}{|c|}{ Calculated percentage contribution to ME $†$} \\
\hline Protein & 54 & 53 \\
\hline Fat & 38 & 35 \\
\hline Carbohydrate & 9 & 12 \\
\hline ME (MJ/kg DM) & $15 \cdot 07$ & $15 \cdot 53$ \\
\hline
\end{tabular}

$\mathrm{ME}$, metabolisable energy.

${ }^{*}$ Containing (per kg): vitamin A, $840 \mathrm{mg}$; vitamin $\mathrm{D}_{3}, 7 \mathrm{mg}$; $\alpha$-tocopherol, $24000 \mathrm{mg}$; vitamin $\mathrm{B}_{1}, 10000 \mathrm{mg}$; vitamin $\mathrm{B}_{2}, 4800 \mathrm{mg}$; vitamin $B_{6}, 3200 \mathrm{mg}$; D-pantothenic acid, $3200 \mathrm{mg}$; niacin, $8000 \mathrm{mg}$; choline chloride, $40000 \mathrm{mg}$; folic acid, $120 \mathrm{mg}$; biotin, $80 \mathrm{mg}$; vitamin $B_{12}$ $8 \mathrm{mg}$; para-amino-benzoic acid, $800 \mathrm{mg}$; zinc bacitracin, $8000 \mathrm{mg}$; Fe, $20 \mathrm{~g} ; \mathrm{Zn}, 12.5 \mathrm{~g} ; \mathrm{Mn}, 6.2 \mathrm{~g} ; \mathrm{Cu}, 1.0 \mathrm{~g}$.

† Calculated from analysed chemical composition and ME factors of $18.42 \mathrm{~kJ} / \mathrm{g}$ digestible protein, $39.76 \mathrm{~kJ} / \mathrm{g}$ digestible fat and $17.58 \mathrm{~kJ} / \mathrm{g}$ digestible carbohydrate (Hansen et al. 1991).

\section{Weighing and blood sampling of animals}

The dams were weighed when the animals entered the laboratory, at the start of each balance period and at the end of the experiment. Mink kits were weighed at birth and then weekly. Blood samples were taken mainly at the same time points as described earlier, the exception being the period about the time of expected implantation, when blood samplings were omitted in order not to disturb the implantation process (Tauson, 1991). During blood sampling the animals were held in a conventional mink trap and blood was withdrawn by puncture of Vena cephalica antebrachii (Blixenkrone-Møller et al. 1987). Anaesthesia was not given in order to avoid interference with hormone release. To circumvent diurnal variation in hormone concentrations, blood was sampled from 09.00 to 11.30 hours. Blood was collected in heparinised tubes, and the separated plasma was stored in plastic tubes at $-18^{\circ} \mathrm{C}$ until assay.

\section{Analytical procedures, food and excreta}

The diets and faeces were analysed for DM by evaporation at $100^{\circ} \mathrm{C}$ to constant weight. Ash was determined by combustion at $525^{\circ} \mathrm{C}$ for $6 \mathrm{~h}, \mathrm{~N}$ was determined by the micro-Kjeldahl technique with the Tecator-Kjeltec system 1030 (Tecator AB, Höganäs, Sweden), crude protein was calculated as $\mathrm{N} \times 6 \cdot 25$, fat was determined by petroleum-diethyl ether extraction after $\mathrm{HCl}$ hydrolysis and gross energy was determined by the use of an adiabatic bomb calorimeter. $\mathrm{CHO}$ were calculated by the difference. Urine was analysed for gross energy and $\mathrm{N}$.

\section{Analytical procedures, hormones and metabolites}

Leptin. Plasma concentrations of leptin were determined by radioimmunoassay (Multispecies leptin radioimmunoassay kit; Linco Research Inc., St Charles, MO, USA) previously validated for mink plasma (Tauson \& Forsberg, 2002). All samples were run in one assay, and the within-assay $\mathrm{CV}$ estimated from the precision profile was $<10 \%$ for concentrations between 1 and $10 \mathrm{ng} / \mathrm{ml}$. The $\mathrm{CV}$ of a human leptin quality control sample provided with the kit was $6 \%$ (mean value $4.2 \mathrm{ng} / \mathrm{ml}$ ).

Thyroid hormones. Plasma concentrations of total triiodothyronine $\left(\mathrm{TT}_{3}\right)$ and total and free thyroxine $\left(\mathrm{TT}_{4}\right.$ and $\mathrm{FT}_{4}$ ) were analysed by the use of a commercial chemiluminescence immunoassay (Amerlite; Johnson and Johnson, Amersham, UK). Serial dilutions of mink plasma with high concentrations of $\mathrm{TT}_{3}, \mathrm{TT}_{4}$ and $\mathrm{FT}_{4}$ produced displacement curves parallel to the standard curves of the respective assays. The intra-assay $\mathrm{CV}$ for $\mathrm{TT}_{3}$ were below $10 \%$ for all concentrations, and the corresponding inter-assay CV were $21.8 \%$ for samples with low concentrations (mean $1.1 \mathrm{nmol} / \mathrm{l}$ ) and $10.2 \%$ (mean $3.0 \mathrm{nmol} / \mathrm{l}$ ) and $8.0 \%$ (mean $6.1 \mathrm{nmol} / \mathrm{l}$ ) for samples with medium and high concentrations, respectively. For $\mathrm{TT}_{4}$ the intra-assay CV were $14.3 \%$ for samples with low concentrations (mean $6.0 \mathrm{nmol} / \mathrm{l}$ ), $6.0 \%$ (mean $20.6 \mathrm{nmol} / \mathrm{l}$ ) for medium concentrations and $4.1 \%$ (mean $73.4 \mathrm{nmol} / \mathrm{l}$ ) for samples with high concentrations, and the inter-assay $\mathrm{CV}$ were $26.1 \%$ for low, $3.6 \%$ for medium and $5.0 \%$ for high concentrations. For $\mathrm{FT}_{4}$ the intra-assay $\mathrm{CV}$ were below $10 \%$ for all concentrations, and the corresponding 
inter-assay CV were $18.8 \%$ for samples with low concentration (mean 12.2 pmol/l) and below $10 \%$ for samples with medium (mean $21.9 \mathrm{pmol} / \mathrm{l}$ ) and high (mean $41.9 \mathrm{pmol} / \mathrm{l}$ ) concentrations.

Insulin. Plasma concentrations of insulin were determined by radioimmunoassay (Pharmacia insulin RIA; Kabi-Pharmacia, Uppsala, Sweden). Serial dilutions of mink plasma containing high concentrations of insulin produced a dose-response curve parallel to the standard curve. The intra-assay $\mathrm{CV}$ for quality control samples were $5.4 \%$ (mean $12 \mu \mathrm{U} / \mathrm{l}$ ), $5.3 \%$ (mean $42 \mu \mathrm{U} / \mathrm{l}$ ) and $5.3 \%$ (mean $117 \mu \mathrm{U} / \mathrm{l}$ ). The corresponding inter-assay $\mathrm{CV}$ were $7.8,2.2$ and $6.7 \%$.

Insulin-like growth factor-1. The plasma concentration of insulin-like growth factor-1 (IGF-1) was determined by radioimmunoassay according to the manufacturer's recommendations (IGF-1, catalogue no. 53065; Incstar Corporation, Stillwater, MI, USA). Plasma was extracted with ODC-silica columns before assay. Serial dilutions of mink plasma with high concentrations of IGF-1 produced displacement curves parallel to the human standard curve. The intra-assay $\mathrm{CV}$, calculated from the precision profiles of five assays, was below $12 \%$ for IGF-1 concentrations between 2.9 and $82.5 \mathrm{nmol} / \mathrm{l}$. The inter-assay $\mathrm{CV}$ for two control samples were $19 \%$ (mean $10 \mathrm{nmol} / \mathrm{l}$ ) and $21 \%$ (mean $28 \mathrm{nmol} / \mathrm{l}$ ). The minimum detectable level of IGF-1 was set to $2 \mathrm{nmol} / \mathrm{l}$ (average $10 \%$ fall from '0'-binding of five assays).

Prolactin. Plasma was analysed for prolactin with an enzyme immunometric assay designed for canine prolactin (Milenia canine prolactin; Diagnostic Products Corporation, Los Angeles, CA, USA) as described by Xiao et al. (1995). The intra-assay CV calculated from the precision profiles was below $10 \%$ for concentrations between 2 and $40 \mathrm{ng} / \mathrm{ml}$. The inter-assay $\mathrm{CV}$ for a control sample with $4.7 \mathrm{ng} / \mathrm{ml}$ was $8.9 \%$. The detection limit according to the manufacturer's information was $0.5 \mathrm{ng} / \mathrm{ml}$.

Glucose and fructosamine. Plasma concentrations of glucose and fructosamine were analysed in a computerised multichannel spectrophotometer (Cobas Mira; HoffmannLa Roche \& Co., Basel, Switzerland). The analysis of glucose was performed according to Bondar \& Mead (1974) and fructosamine was analysed by measuring formazane at $550 \mathrm{~nm}$ (Baker et al. 1985). The inter-assay CV were 1.6 and $3 \%$, respectively.

\section{Calculations}

ME was calculated as $\mathrm{ME}=$ gross energy - energy in faeces - energy in urine. Heat production (HE) was calculated from $\mathrm{O}_{2}$ consumption, $\mathrm{CO}_{2}$ production and urinary $\mathrm{N}$ (UN) according to the formula by Brouwer (1965):

$$
\begin{aligned}
\mathrm{HE}(\mathrm{kJ})= & 16.18 \times \mathrm{O}_{2} \text { (litres) }+5.02 \times \mathrm{CO}_{2} \text { (litres) } \\
& -5.99 \times \mathrm{UN}(\mathrm{g}) .
\end{aligned}
$$

Retained energy was calculated as ME - HE for pregnant dams. For lactating dams no such calculation was done because energy output in milk was not measured.

Quantitative oxidation values for protein (OXP), fat (OXF) and $\mathrm{CHO}(\mathrm{OXCHO})$ were calculated based on gas exchange measurements and $\mathrm{UN}$ as described and validated for pigs by Chwalibog et al. (1992)

$$
\begin{aligned}
& \mathrm{OXP}(\mathrm{kJ})=\mathrm{UN}(\mathrm{g}) \times 6.25 \times 18.42 ; \\
& \mathrm{OXF}(\mathrm{kJ})=(1.719 \times \mathrm{O}_{2}(\text { litres })-1.719 \times \mathrm{CO}_{2}(\text { litres }) \\
&-1.963 \times \mathrm{UN}(\mathrm{g})) \times 39.76 ; \\
& \mathrm{OXCHO}(\mathrm{kJ})=\left(-2.968 \times \mathrm{O}_{2}(\text { litres })+4.174\right. \\
&\left.\times \mathrm{CO}_{2}(\text { litres })-2.446 \times \mathrm{UN}(\mathrm{g})\right) \\
& \times 17.58
\end{aligned}
$$

Although balance and respiration experiments were performed in consecutive 1 -week periods, the results are reported in relation to time of parturition. Hence, the interval between each respiration experiment and parturition was calculated. The results are reported for periods corresponding to before implantation (BEFIMP; $\geq 33 \mathrm{~d}$ prepartum), about the time of implantation (IMP; 27-32 d prepartum, no hormones and metabolites), during the first third of true gestation (GEST1/3; 18-26d prepartum), during the second third of true gestation (GEST2/3; 9-17 d prepartum), during the last third of true gestation (GEST3/3; $\leq 8 \mathrm{~d}$ prepartum) and during the first (LACTW1), second (LACTW2), third (LACTW3) or fourth (LACTW4) week of lactation.

During the lactation period, respiration experiments were performed with the dams and their litters. When relating the results to metabolic weight $\left(\mathrm{kg}^{0.75}\right)$, the metabolic weight of the dam and the mean kit metabolic weight multiplied by the number of kits in the litter made up the total metabolic weight of dam and litter.

\section{Statistical analyses}

The statistical analyses were performed according to the MIXED procedure in SAS ${ }^{\circledR}$ (Littell et al. 1996). The material was analysed regarding the fixed effect of physiological stage as the repeated measure (BEFIMP, IMP, GEST1/3, GEST2/3 or GEST3/3, LACTW1, LACTW2, LACTW3 or LACTW4). The autoregressive order 1 (AR1) covariance structure was fitted. Pearson correlation coefficients were calculated for selected traits (SAS Institute, Inc., 1990).

\section{Results}

\section{Reproductive performance and kit weight gain}

All dams entering the experiment turned out to be pregnant and gave birth after a gestation period of on average $46 \cdot 8$ (SD 3.27) d. Average total litter size at birth was 7.7 (SD 2.69) kits of which 7.0 were liveborn. Stillborn kits hence accounted for $8.7 \%$ of the total born which is a normal level for the litter size. Total litter size ranged from three to twelve kits, and the number of stillborn kits ranged from zero to two. The number of kits per litter during the suckling period (after cross-fostering) was 5.7 (SD 1.12). Kit birth weight was normal and amounted to 9.1 (SD 1.77) g. From then on kits gained weight at a normal rate and reached live weights (LW) of 89.5 (SD 18.37) $\mathrm{g}$ in LACTW3 (day 17 (SD 1.98) 
postpartum) and then at the end of the experiment in the fifth week of lactation (day 31 (SD 2.09) postpartum) $192 \cdot 1$ (SD 21.22) g.

\section{Intake of metabolisable energy and dam live weights}

The intake of ME $\left(\mathrm{kJ} / \mathrm{kg}^{0.75}\right)$ was high during BEFIMP, IMP and GEST1/3 and not significantly different between any of these stages. From then on it declined during GEST2/3 and further to a very low level during GEST3/3, the period of the most extensive fetal growth; differences between the previous stages $(P<0.05)$ and between the two latter stages $(P<0.001)$ being significant (Table 2). During LACTW1, ME intake had increased to the same level as during BEFIMP, IMP and GEST1/3. During each of the following weeks intake increased significantly $(P<0.05)$, the amount consumed during LACTW4 being approximately twice that consumed during LACTW1 (Table 2).

Dam LW increased from BEFIMP until GEST2/3 $(P<0.001)$, but there was a non-significant $(P=0.15)$ decline from GEST2/3 to GEST3/3 (Table 2), suggesting that part of the fetal growth was supported by maternal body reserves. During LACTW1, LW was below the prepartum weight $(P<0.01)$, and LW decreased throughout LACTW1 to LACTW4, the decline being close to significant $(P=0.08)$ (Table 2$)$, indicating that the dams continued to mobilise energy.

\section{Energy metabolism}

$\mathrm{HE}$ of pregnant dams ranged from 625 to $710 \mathrm{~kJ} / \mathrm{kg}^{0.75}$, the differences between stages being non-significant, but there was a tendency for an increase from GEST1/3 to GEST2/3, simultaneous with declining ME intake. When relating $\mathrm{HE}$ to $\mathrm{ME}$ intake, HE made up $88 \%$ (BEFIMP), $76 \%$ (IMP), $82 \%$ (GEST1/3), $101 \% \quad($ GEST $2 / 3)$ and $163 \%$ (GEST3/3), indicating an increased HE in late gestation. For lactating dams with their litters, HE, when calculated in relation to metabolic body weight of the dam, increased as lactation progressed. Another approach, in which $\mathrm{HE}$ was calculated in relation to metabolic weight of both dam and litter, revealed HE values ranging from 534 to $604 \mathrm{~kJ} / \mathrm{kg}^{0.75}$, differences between lactation weeks being non-significant (Table 2). Because kit $\mathrm{HE}$ values could not be separated from those of the dam, it was not possible to deduce whether the dam's contribution increased as lactation progressed and food intake and milk yield increased. In pregnant dams, retained energy was positive until GEST1/3, slightly negative $\left(-6 \mathrm{~kJ} / \mathrm{kg}^{0 \cdot 75}\right)$ during GEST $2 / 3$ and strongly negative $\left(-262 \mathrm{~kJ} / \mathrm{kg}^{0.75}\right)$ during GEST3/3. Because energy retained as protein was positive throughout gestation, the proportion of energy retained as fat was clearly negative already during GEST $2 / 3$, thus indicating mobilisation of body fat during GEST2/3 (Table 2).

\section{Substrate oxidation}

The oxidation of protein as a percentage of HE (OXP/HE) reflected the intake of $\mathrm{ME}$, with the highest values being recorded during IMP and GEST1/3 when ME intake was 
high. There was also a clear reflection of the protein requirement for retention in fetal tissues, resulting in $\mathrm{OXP} / \mathrm{HE}$ decreasing significantly to GEST2/3 $(P=0 \cdot 001)$ and then further to GEST3/3 $(P=0.002)$, when the lowest value of $25 \%$ of $\mathrm{HE}$ was recorded. The oxidation of fat $(\mathrm{OXF} / \mathrm{HE})$ in pregnant dams was the reverse of $\mathrm{OXP} / \mathrm{HE}$, with high values during periods with low ME intake and low values when the dams were in positive energy balance. The oxidation of $\mathrm{CHO}$ in pregnant dams reflected that all dietary $\mathrm{CHO}$ was oxidised (Fig. 1). Among lactating dams there were no significant differences in substrate oxidation. The oxidation of protein made up slightly more than $35 \%$ of $\mathrm{HE}$, whereas OXF ranged from slightly below $35 \%$ to slightly above $42 \%$ while all dietary $\mathrm{CHO}$ were oxidised (Fig. 1).

\section{Nitrogen metabolism}

Ingested $\mathrm{N}$, digested $\mathrm{N}$ and $\mathrm{UN}$ generally mirrored the intakes of $\mathrm{ME}$ with high values during periods of high energy intake. The retained $\mathrm{N}(\mathrm{RN})$ of pregnant dams, similarly, reflected to a large extent ME intake, with values about $0.5 \mathrm{~g} / \mathrm{d}$ during all stages but GEST3/3, when it was less than one half of this. The RN data recorded for lactating dams were to a large extent a reflection of $\mathrm{N}$ excretion in milk because no milk production measurements were made, and it was therefore not possible to separate $\mathrm{N}$ excretion in milk from $\mathrm{N}$ balance in the body. The $\mathrm{RN}$ values increased from $0.75 \mathrm{~g} / \mathrm{d}$ during LACTW1 to about $1.40 \mathrm{~g} / \mathrm{d}$ in LACTW4 (Fig. 2). Also, the utilisation of the digested protein for retention (RN/digested $\mathrm{N}$; \%) was strongly affected by stage. Generally, the utilisation was lower in pregnant dams, for whom it ranged from $10 \%(\mathrm{GEST} 3 / 3)$ to $18 \%$ (GEST2/3), this difference

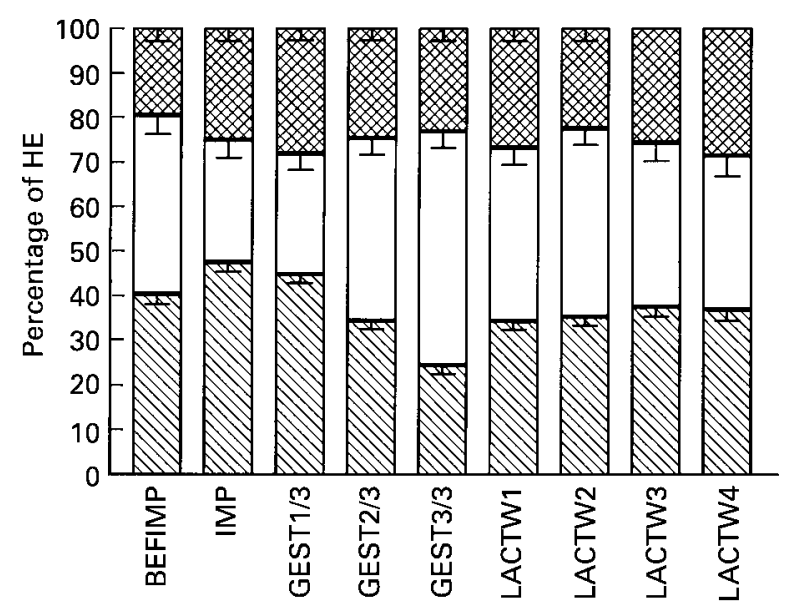

Fig. 1. Oxidation of protein $(\mathbb{\mathbb { N }})$, fat $(\square)$ and carbohydrate $(\otimes)$ in percentage of total heat production $(\mathrm{HE})$ in nine pregnant or lactating mink dams measured before implantation (BEFIMP; -36.4 (SEM 0.73) d prepartum), about the time of implantation (IMP; - 29.1 (SEM 0.82) d prepartum), during the first (GEST1/3; - 21.9 (SEM 0.60) d prepartum), second (GEST2/3; - 12.9 (SEM 0.60) d prepartum) and last third (GEST3/3; - 4.7 (SEM 0.60) d prepartum) of true gestation and during weeks 1 (LACTW1; 4.4 (SEM 0.67) d postpartum), 2 (LACTW2; 10.6 (SEM 0.77) d postpartum), 3 (LACTW3; 18.3 (SEM 0.73) d postpartum) and 4 (LACTW4; 26.6 (SEM 0.67 ) d postpartum) of lactation. Mean values are shown, with standard errors of the mean represented by vertical bars. being significant $(P=0 \cdot 01)$, than in lactating dams, for whom it was about $25 \%$ without significant differences between lactation weeks. All differences between pregnant and lactating dams but BEFIMP to LACTW3, BEFIMP to GEST3/3, GEST2/3 to LACTW1 and LACTW3, and finally, GEST2/3 to GEST3/3, were significant $(P<0 \cdot 05)$.

\section{Hormones and metabolites}

Leptin and insulin. Plasma concentrations of leptin were significantly affected by measurement period $(P=0 \cdot 02)$. They decreased non-significantly from BEFIMP to GEST1/3, but in GEST2/3 a more than doubled concentration was recorded (difference between the two periods; $P=0.008$ ), and this high level also remained during GEST3/3. Immediately after parturition (LACTW1), concentrations returned to the same level as during GEST1/3, and they remained in the same order throughout the measurement period (Fig. 3 (a)). During the gestation period there was a significant negative correlation between intake of ME/ $\mathrm{kg}^{0.75}$ and leptin $(r-0.41 ; P=0.003)$, but during lactation there was no such correlation. Similarly, leptin and retained energy were negatively correlated $(r-0.29 ; P=0.04)$ in pregnant dams. No significant correlation between HE and leptin was recorded for either pregnant or lactating dams.

For insulin, strongly significant effects of the measurement period were also recorded $(P<0 \cdot 001)$, but the pattern did not follow that of leptin. Instead, concentrations decreased from BEFIMP until GEST3/3 $(P<0 \cdot 001)$. Insulin remained low during lactation, and there were no significant differences between lactation weeks. Only in LACTW3 was a concentration significantly higher than during GEST3/3 $(P=0.05)$ recorded (Fig. 3 (a)). There was no significant correlation between insulin and leptin for either pregnant or lactating dams.

Thyroid hormones. Among the thyroid hormones the patterns of $\mathrm{TT}_{4}$ and $\mathrm{FT}_{4}$ mirrored each other to a large

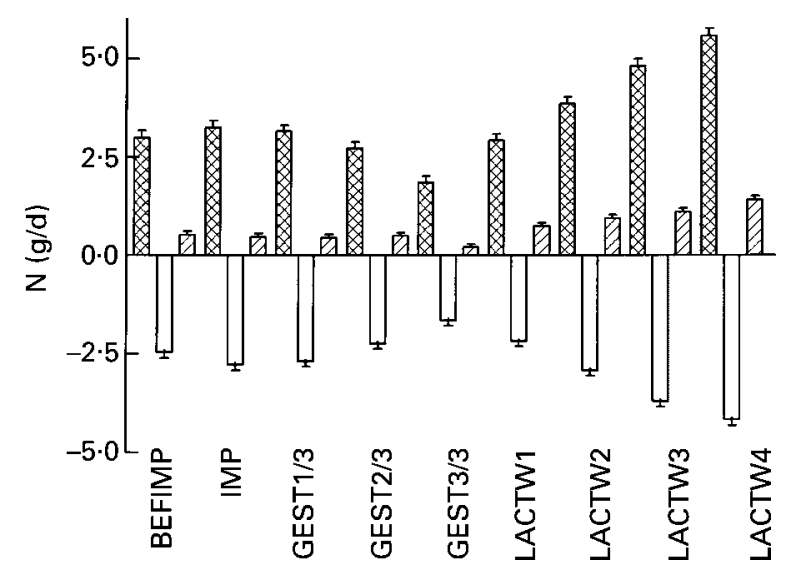

Fig. 2. Nitrogen metabolism of nine pregnant or lactating mink dams measured in balance periods before implantation (BEFIMP), about the time of implantation (IMP), during the first (GEST1/3), second (GEST2/3) and last third (GEST3/3) of true gestation and during weeks 1 (LACTW1), 2 (LACTW2), 3 (LACTW3) and 4 (LACTW4) of lactation. Data presented are digested $N\left(x^{2}\right)$, urinary $N(\square)$ and retained nitrogen $(\mathbb{C})$. Mean values are shown, with standard errors of the mean represented by vertical bars. 
(a)

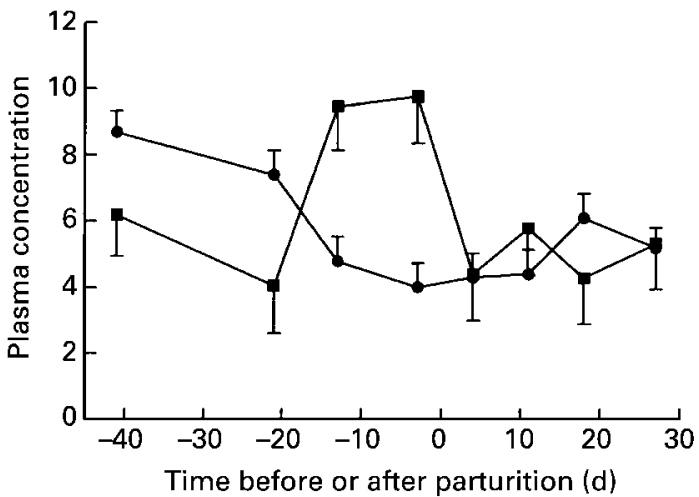

(c)

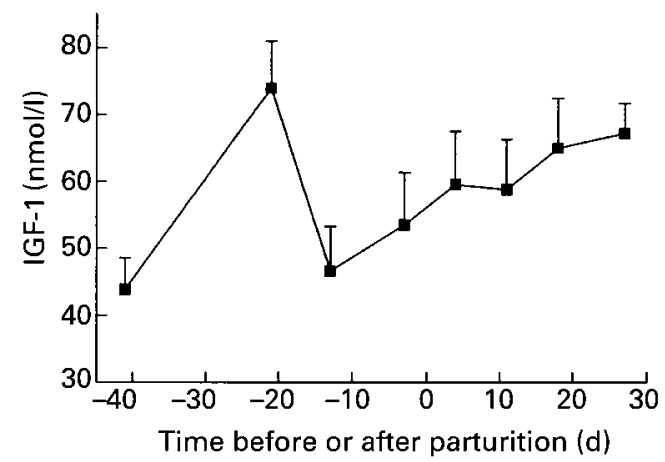

(b)
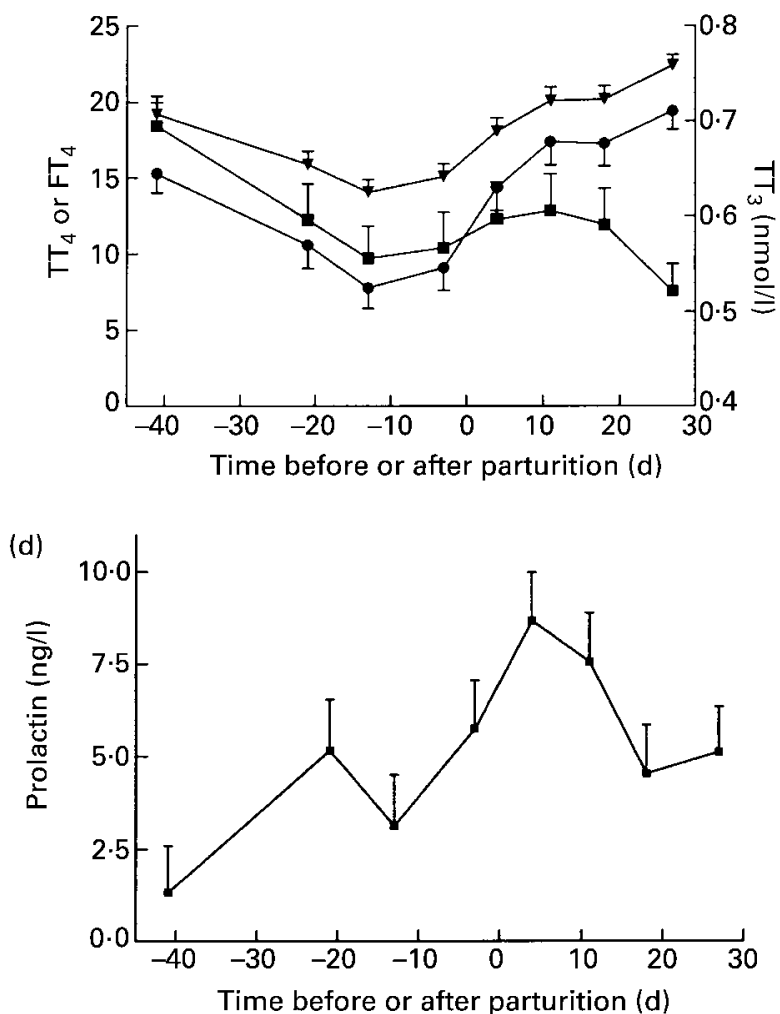

Fig. 3. Plasma concentrations of (a) leptin $(\mathbf{\square} ; \mathrm{ng} / \mathrm{ml})$ and insulin $(\bullet ; \mu \mathrm{U} / \mathrm{l}) ;$ (b) total thyroxine $\left(\mathrm{TT}_{4} ; \bullet ; \mathrm{nmol} / \mathrm{l}\right)$, free thyroxine $\left(\mathrm{FT} \mathrm{f}_{4} ; \mathbf{v} ; \mathrm{pmol} / \mathrm{l}\right)$ and total triiodothyronine ( $\left.\mathbf{a} ; \mathrm{TT}_{3}\right)$; (c) insulin-like growth factor 1 (IGF-1); (d) prolactin in nine mink dams blood-sampled before implantation (BEFIMP; - 40.7 (SEM 0.66) d prepartum), during the first (GEST1/3; - 21.2 (SEM 0.78) d prepartum), second (GEST2/3; - 12.8 (SEM 0.78) d prepartum) and last third (GEST3/3; - 3.4 (SEM 0.82) d prepartum) of true gestation and during weeks 1 (LACTW1; 3.8 (SEM 0.92) d postpartum), 2 (LACTW2; 10.7 (SEM 0.99) d postpartum), 3 (LACTW3; 18.1 (SEM 0.92) d postpartum) and 4 (LACTW4; 27.4 (SEM 0.60) d postpartum) of lactation. Mean values are shown, with standard errors of the mean represented by vertical bars.

extent. Concentrations declined from BEFIMP to true gestation, differences being significant $\left(\mathrm{TT}_{4}, P<0 \cdot 05 ; \mathrm{FT}_{4}\right.$, $P<0.01)$, and by LACTW1 they had returned to the same level as BEFIMP. For both hormones, concentrations continued to increase throughout the four lactation weeks, the difference between LACTW1 and LACTW4 being significant $\left(\mathrm{TT}_{4}, P=0.01 ; \mathrm{FT}_{4}, P<0.001\right.$ ) (Fig. 3 (b)). The relationship between $\mathrm{FT}_{4}$ and $\mathrm{TT}_{4}$ did, however, vary with stage $(P<0.001)$; it increased from $0.125 \%$ $\mathrm{FT}_{4}$ during BEFIMP to $0 \cdot 18 \%$ during GEST2/3. During lactation there was a slight decline from $0.126 \% \mathrm{FT}_{4}$ in LACTW1 to $0.115 \%$ in LACTW2, this level remaining constant during the following weeks. There were weak negative correlations between plasma concentrations of thyroxine $\left(\mathrm{T}_{4}\right)$ and leptin in pregnant and lactating dams $\left(\mathrm{TT}_{4}, r-0.22, P=0.02 ; \mathrm{FT}_{4}, r-0.20, P=0.04\right)$. For $\mathrm{TT}_{3}$ a different pattern was recorded; it showed a decline similar to that of $\mathrm{TT}_{4}$ and $\mathrm{FT}_{4}$ from BEFIMP to GEST3/3 $(P=0.01)$, but then it remained on the same level throughout the four lactation weeks (Fig. 3 (b)). In pregnant dams $\mathrm{TT}_{3}$ increased progressively in relation to $\mathrm{TT}_{4}$ from $13.6 \%$ in BEFIMP to $21.5 \%$ in GEST3/3. In lactating dams the relationship between $\mathrm{TT}_{3}$ and $\mathrm{TT}_{4}$ remained stable, with $\mathrm{TT}_{3}$ making up about $12 \%$ of the $\mathrm{TT}_{4}$ concentration. There was no correlation between $\mathrm{TT}_{3}$ and leptin but between $\mathrm{TT}_{3}$ and insulin $(r 0.25 ; P=0.01)$ when pregnant and lactating dams were considered together.
Insulin-like growth factor-1. Plasma concentrations of IGF-1 were low during BEFIMP and then increased significantly $(P<0 \cdot 001)$ in GEST1/3, declining to BEFIMP levels during GEST2/3 and GEST3/3, when food intake was low. Although there was a tendency for an increase in IGF-1 concentrations during lactation there were no differences between lactation weeks and concentrations were not significantly different from those during GEST3/3 (Fig. 3 (c)).

Prolactin. The BEFIMP period was characterised by very low prolactin concentrations, but they increased significantly to GEST1/3 $(P<0 \cdot 05)$. After a slight decrease during GEST2/3, concentrations increased again in GEST3/3. The highest concentration was recorded during LACTW1, and then lower concentrations were recorded during LACTW3 $(P<0.05)$ and LACTW4 (NS) (Fig. $3(\mathrm{~d})$ ).

Glucose. Plasma glucose showed a pattern similar to that of insulin, with declining concentrations from BEFIMP to late true gestation $(P<0.05)$. Indeed, during LACTW1 concentrations even lower than during GEST3/3 were recorded $(P<0 \cdot 05)$, but then concentrations increased and had reached BEFIMP levels by LACTW4 although insulin concentrations remained low (data not shown). Correlations between glucose and leptin and insulin, respectively, were not significant.

Fructosamine. Plasma concentrations of fructosamine were not significantly affected by stage of gestation or 
lactation, and they showed no general conclusive pattern (data not shown).

\section{Discussion}

The present data have clearly demonstrated the occurrence of elevated plasma concentrations of leptin during GEST2/3 in mink. The magnitude of the increase was slightly higher than that reported for human subjects (Hardie et al. 1997; Highman et al. 1998; Schubring et al. 1998; Sivan et al. 1998), about the same as in rats (Kawai et al. 1997; Amico et al. 1998) but considerably lower than in mice (Gavrilova et al. 1997; Tomimatsu et al. 1997). The pattern in mink does not concur completely with findings in sheep, in which high leptin concentrations have been recorded in mid- (Ehrhardt et al. 2001) but not in late pregnancy (Ehrhardt et al. 2001; M Tygesen, A-H Tauson, MO Nielsen, D Blache, T Jensen, K Kortegaard, AB Jensen, P Nørgaard and $\mathrm{H}$ Raring, unpublished results).

High leptin concentrations could be caused by a high food intake and increasing adiposity as well as by high insulin concentrations as would be expected in non-pregnant animals (mink, Tauson \& Forsberg, 2002; other species, Baile et al. 2000; Havel, 2000; Schwartz et al. 2000; Frübeck, 2001). This was certainly not the case in the present study, because the animals, despite free access to food, decreased their food intake during GEST2/3, resulting in a negative energy balance, fat mobilisation and decreasing $\mathrm{LW}$ during the late part of gestation. This is also contrary to findings in other species, in which gestational hyperleptinaemia is not accompanied by a decrease in food intake and mobilisation of body fat (human subjects, Butte et al. 1997; Highman et al. 1998; Schubring et al. 1998). Gestational hyperleptinaemia may be caused partly by the secretion of placenta-derived leptin (human subjects, Masuzaki et al. 1997; Señarís et al. 1997; baboons, Henson et al. 1999; rats, Amico et al. 1998; García et al. 2000), a possibility that cannot be excluded in the present experiment. Also, a mechanism similar to that in mice, where the gestational hyperleptinaemia is attributed to the binding of leptin to the soluble form of the leptin receptor secreted from the placenta (Gavrilova et al. 1997), could be possible in the mink. Another cause of high leptin concentrations during pregnancy could be the secretion of hormones that may stimulate leptin secretion. Among these are oestrogens and insulin. We previously demonstrated a high correlation between plasma insulin and leptin in non-pregnant mink dams and during GEST1/3 ( $r$ 0.75, $P<0.001$; Tauson \& Forsberg, 2002). However, because insulin concentrations declined in late gestation when food intake was low, which is in accordance with previous findings in mink demonstrating a close relationship between food intake and plasma insulin (Fink \& Tauson, 1998; Fink et al. 1998; Tauson et al. 2000), the hyperleptinaemia found in the present study could not be explained by the stimulation by high insulin concentrations. Oestrogen seems more likely to have exerted stimulation because high concentrations of oestradiol-17 $\beta$ occur during the late part of gestation in mink (Tauson, 1991).

Elevated leptin concentrations were recorded after the period of high food intake and positive energy balance at
IMP and during GEST1/3, and concentrations remained high during the period with low food intake, negative energy balance and high rate of fat oxidation. Indeed, in gestation there were significant negative correlations between leptin and ME intake as well as leptin and retained energy. If the increase in leptin had been a response to normal feedback mechanisms, a decline in response to the suppression of food intake during the last $20 \mathrm{~d}$ of gestation would have been expected. These findings and the lack of a correlation between $\mathrm{HE}$ and leptin are in conflict with the normal regulation of leptin in response to food intake and adiposity, and they indicate that leptin is regulated differently in pregnant mink than in non-pregnant animals.

Thyroid hormone concentrations declined during the last $20 \mathrm{~d}$ of true gestation, which probably reflected the low food intake and the negative energy balance. However, there is evidence that the thyroid axis may influence leptin secretion and metabolism, but it seems that the mechanisms may differ between species. Hypothyroid rats have increased leptin concentrations, but the infusion of thyroid hormones exerts an inhibitory effect on leptin concentrations (Escobar-Morreale et al. 1997; Leonhardt et al. 1999). This effect was maintained over a wide range of thyroid hormone levels representing states from severe hypothyroidism to hyperthyroidism, and supply of both exogenous triiodothyronine $\left(\mathrm{T}_{3}\right)$ and $\mathrm{T}_{4}$ had inhibitory effects (Escobar-Morreale et al. 1997). Furthermore, there is evidence that the effects of leptin and $\mathrm{T}_{3}$ on oxidative metabolism in rats are additive and independent of thyroid status, as demonstrated by the normalisation of $\mathrm{O}_{2}$ consumption and $\mathrm{CO}_{2}$ production in thyroidectomised rats after treatment with $\mathrm{T}_{3}$ or leptin and treatment with both $\mathrm{T}_{3}$ and leptin giving an additive response (Wang et al. 2000). Our finding of a weak negative correlation between $\mathrm{TT}_{4}$ and $\mathrm{FT}_{4}$ and leptin hence concurs with the rat results, whereas the lack of a relationship between $\mathrm{TT}_{3}$ and leptin is not in full agreement with Escobar-Morreale et al. (1997). On the other hand, also with a substantial increase in plasma leptin by means of peripheral infusion, plasma concentrations of $\mathrm{TT}_{4}$ remained stable in well-fed lambs (Morrison et al. 2002).

The main part of fetal growth occurs very late in gestation in mink (Tauson et al. 1991, 1994), and therefore these results imply that a significant part of the accretion in fetal tissues was derived from nutrients mobilised from the body of the dams. $\mathrm{N}$ retention was positive throughout gestation, so the main contribution was made up by fat mobilisation. In other species (rats, Naismith \& Morgan, 1976; Pine et al. 1994; sheep, McNeill et al. 1997) there may be a substantial accretion of labile protein reserves during pregnancy. These reserves may be used if the protein supply is insufficient in late gestation or may provide an important contribution for sustaining milk production in early lactation. Because $\mathrm{N}$ retention in early gestation in the present study was far higher than what could be expected for retention in fetal tissue (Tauson et al. 1991, 1994), these data suggest that the pregnant mink dam accretes a labile protein reserve. The oxidation of protein reflected the increasing protein requirement with progressing stage of gestation by 
decreasing values; from $48 \%$ (IMP) to the lowest level of $25 \%$ of HE (GEST3/3). These values are considerably higher than 11-13\% of $\mathrm{HE}$ as reported for pregnant sows (Theil et al. 2002). Also, the relatively low utilisation of digested $\mathrm{N}$ for retention showed that the protein supply was clearly above the requirement throughout the gestation period.

Leptin has been suggested to be an important growth factor for the fetus (Mostyn et al. 2001), but the possible mechanisms remain unclear. Positive correlations between cord-blood leptin concentrations and the birth weight of infants have been reported in some studies (Harigaya et al. 1997; Koistinen et al. 1997), but Schubring et al. (1998) found no correlation between maternal leptin concentration, cord-blood concentration and birth weight. In an adolescent sheep pregnancy model there was, however, a clear negative relationship between leptin in the maternal circulation and lamb birth weight (Thomas et al. 2001). In this investigation the maternal hyperleptinaemia was recorded during the period of most intensive fetal growth so a growth-promoting role for the mink fetus cannot be excluded, but as the origin of the circulating leptin is not known this remains a speculation.

Similar to those in other species (human subjects, Hardie et al. 1997; Schubring et al. 1998; Sivan et al. 1998; rat, Kawai et al. 1997; Amico et al. 1998; Brogan et al. 1999; Woodside et al. 2000), plasma leptin concentrations declined shortly after parturition and remained low. This is in agreement with findings in sheep (Ehrhardt et al. 2001; M Tygesen, A-H Tauson, MO Nielsen, D Blache, $\mathrm{T}$ Jensen, $\mathrm{K}$ Kortegaard, $\mathrm{AB}$ Jensen, $\mathrm{P}$ Nørgaard and $\mathrm{H}$ Raring, unpublished results) and cattle (Block et al. 2001). The reason for the decline in leptin in lactation is probably the high energetic demands for maintaining a high milk yield. Hence, it has been demonstrated in rats (Brogan et al. 1999; Woodside et al. 2000) and cattle (Block et al. 2001) that if the energetic costs of lactation are eliminated, plasma leptin concentrations increase. Low plasma concentrations in early lactation may also have a beneficial effect in being permissive for lactational hyperphagia. ME intake increased by 3.5 times from GEST3/3 to LACTW4. Despite this, the dams were unable to sustain their energy requirement by food intake alone, as shown by declining LW. The use of data from Fink et al. (2001) on milk yield and energy output in milk in a mink dam suckling six kits confirmed that a substantial mobilisation of body reserves was necessary to nurture the kits in this investigation. Another factor that might have contributed to the low plasma leptin concentrations during lactation was the increasing concentrations of $\mathrm{TT}_{4}$ and $\mathrm{FT}_{4}$, which could exert an inhibitory effect on leptin (Escobar-Morreale et al. 1997; Leonhardt et al. 1999).

The patterns of food intake and energy balance were generally reflected in the plasma concentrations of IGF-1, which in turn were not clearly related to concentrations of leptin. Similarly, in periparturient dairy cows, plasma IGF-1 concentrations were depressed during periods of negative energy balance (Block et al. 2001). Exogenous leptin supply did not cause the modification of IGF-1 release in sheep on reduced nutrition (Nagatani et al. 2000) or in the well-fed state (Morrison et al. 2002), so collectively these data indicate that the interaction between nutritional status, leptin and IGF-1 is not clearly elucidated.

Reproduction in mink is highly dependent on photoperiod. Prolactin, which is luteotrophic in mink (Papke et al. 1980), starts to rise over basal concentrations about the time of the vernal equinox, and it might be permissive for the increase in food intake in the period of IMP because in mink dams that were not mated prolactin concentrations remained at basal levels, food intake was low and animals lost weight (Tauson, 1997). Conversely, if exogenous prolactin implants were given to females that were not mated, food intake approached the level in mated females (Tauson et al. 1999). Here the prolactin concentrations started to rise before those of leptin. In rats, prolactin may stimulate leptin synthesis (Gualillo et al. 1999), so it can be speculated that the photoperiod-dependent increase in plasma prolactin contributes to the induction of gestational hyperleptinaemia in the mink.

\section{Conclusions}

Hyperleptinaemia during the last $20 \mathrm{~d}$ of gestation in the mink has been demonstrated. This state occurred concomitantly with a low intake of ME, negative energy balance, high rate of fat oxidation and loss of body weight, suggesting that leptin may exert anorexigenic effects in pregnant mink. Decreasing thyroid hormone concentrations may have been permissive for the increase in leptin, and prolactin may also have stimulated leptin synthesis. Plasma leptin concentrations declined rapidly after parturition and remained low allowing for lactational hyperphagia. Despite a 3.5-fold increase in ME intake from the very last part of gestation until LACTW4, dams were unable to sustain their energy requirement solely by food intake and therefore mobilised body reserves, which was reflected in decreasing body weights. The suppression of food intake in late gestation, possibly caused by high circulating leptin concentrations, might be a permissive mechanism for a rapid increase in food intake after parturition. This may be a suitable strategy for an animal that gives birth to altricial young. Such an animal has a moderate nutrient and energy requirement for deposition in fetal tissues, but the lactation period imposes very high energetic demands owing to large litters of rapidly growing young which are completely dependent on their mother's milk for nourishment during the first 4 weeks of life.

\section{Acknowledgements}

The authors are grateful to Merethe Stubgaard and MariAnne Carlsson for skilful laboratory work. The present study was financially supported by The Danish Agricultural and Veterinary Research Council (grant no. 13-4906-1).

\section{References}

Amico JA, Thomas A, Crowley RS \& Burmeister LA (1998) Concentrations of leptin in serum of pregnant, lactating and 
cycling rats and of leptin messenger ribonucleic acid in rat placental tissue. Life Sci 63, 1387-1395.

Anonymous (1986) European Convention for the Protection of Vertebrate Animals Used for Experimental and Other Scientific Purposes. European Treaty Series no. 123. Strasbourg: Council of Europe.

Baile CA, Della-Fera MA \& Martin RJ (2000) Regulation of metabolism and body fat mass by leptin. Ann Rev Nutr 20, $105-127$.

Baker JR, Metcalf PA, Johnson RN, Newman D \& Rietz P (1985) Use of protein based standards in automated colorimetric determination of fructoseamine in serum. Clin Chem 31, $1550-1554$.

Blixenkrone-Møller M, Lund E, Mikkelsen G \& Uttenthal $\AA$ (1987) Blood collection in mink. Scand J Lab Anim Sci 14, 99.

Block SS, Butler WR, Erhardt RA, Bell AW, Van Amburgh ME \& Boisclair YR (2001) Decreased concentration of plasma leptin in periparturient dairy cows is caused by negative energy balance. J Endocrinol 171, 339-348.

Bondar RJL \& Mead DC (1974) Evaluation of glucose-6-phosphate dehydrogenase from Leuconostoc mesenteroides in the hexokinase method for determining glucose in serum. Clin Chem 20, 586-590.

Brogan RS, Mitchell SE, Trayhurn P \& Smith MS (1999) Suppression of leptin during lactation: contribution of the suckling stimulus versus milk production. Endocrinology 14, 2621-2627.

Brouwer E (1965) Report of sub-committee on constants and factors. In Proceedings of the 3rd Symposium on Energy Metabolism. European Association of Animal Production, vol. 11, pp. 441-443 [KL Blaxter, editor]. London: Academic Press.

Butte NF, Hopkinson JM \& Nicolson MA (1997) Leptin in human reproduction: serum leptin levels in pregnant and lactating women. J Clin Endocrinol Metab 82, 585-589.

Caprio M, Fabbrini E, Isidori AM, Aveersa A \& Fabbri A (2001) Leptin in reproduction. Trends Endocrinol Metab 12, 65-72.

Chwalibog A, Jakobsen K, Henckel S \& Thorbek G (1992) Estimation of quantitative oxidation and fat retention from carbohydrate, protein and fat in growing pigs. J Anim Physiol Anim Nutr 68, 123-135.

Cunningham MJ, Clifton DK \& Steiner RA (1999) Leptin's actions on the reproductive axis: perspectives and mechanisms. Biol Reprod 60, 216-222.

Ehrhardt RA, Slepetis RM, Bell AW \& Boisclair YR (2001) Maternal leptin is elevated during pregnancy in sheep. Dom Anim Endocrinol 21, 85-96.

Escobar-Morreale HF, Escobar del Rey F \& Morreale de Escobar G (1997) Thyroid hormones influence serum leptin concentrations in the rat. Endocrinology 138, 4485-4488.

Fink R \& Tauson A-H (1998) Flushing of mink (Mustela vison): effects on energy metabolism and some blood metabolites. Anim Sci 66, 277-284.

Fink R, Tauson A-H \& Forsberg M (1998) Influence of different planes of energy supply prior to the breeding season on blood metabolites in female mink (Mustela vison). Reprod Nutr Dev 38, 107-116.

Fink R, Tauson A-H, Hansen KB, Wamberg S \& Kristensen NB (2001) Energy intake and milk production in mink (Mustela vison) - effect of litter size. Arch Anim Nutr 55, 221-242.

Frübeck G (2001) A heliocentric view of leptin. Proc Nutr Soc 60, 301-318.

García MDC, Casanueva FF, Diéguez C \& Señarís RM (2000) Gestational profile of leptin messenger ribonucleic acid (mRNA) content in the placenta and adipose tissue in the rat, and regulation of the mRNA levels of the leptin receptor subtypes in the hypothalamus during pregnancy and lactation. Biol Reprod 62, 698-703.
Gavrilova O, Barr V, Marcus-Samuels B \& Reitman M (1997) Hyperleptinemia of pregnancy associated with the appearance of a circulating form of the leptin receptor. J Biol Chem 272, 30546-30551.

Gualillo O, Lago F, Garcia M, et al. (1999) Prolactin stimulates leptin secretion by rat white adipose tissue. Endocrinology 140, 5149-5153.

Hansen NE, Finne L, Skrede A \& Tauson A-H (1991) Energiforsyningen hos Mink og Rev (Energy Supply of Mink and Foxes). NJF Utredning/Rapport no. 63. Copenhagen: DSR Forlag, Landbohøjskolen.

Hardie L, Trayhurn P, Abramovich D \& Fowler P (1997) Circulating leptin in women: a longitudinal study in the menstrual cycle and during pregnancy. Clin Endocrinol 47, $101-106$.

Harigaya A, Nagashima K, Nako Y \& Morikawa A (1997) Relationship between concentration of serum leptin and fetal growth. J Clin Endocrinol Met 82, 3281-3284.

Havel PJ (2000) Role of adipose tissue in body-weight regulation: mechanisms regulating leptin production and energy balance. Proc Nutr Soc 59, 359-371.

Henson MC \& Castracane VD (2000) Leptin in pregnancy. Biol Reprod 63, 1219-1228.

Henson MC, Castracane VD, O'Neil JS, et al. (1999) Serum leptin concentrations and expression of leptin transcripts in placental trophoblast with advancing baboon pregnancy. J Clin Endocrinol Metab 84, 2543-2549.

Highman TJ, Friedman JE, Huston LP, Wong WW \& Catalano PM (1998) Longitudinal changes in maternal serum leptin concentrations, body composition, and resting metabolic rate in pregnancy. Am J Obstet Gynecol 178, 1010-1015.

Jørgensen G \& Glem-Hansen N (1973) A cage designed for metabolism and nitrogen balance trials with mink. Acta Agric Scand 23, 3-5.

Kawai M, Yamaguchi M, Murakami T, Shima K, Murata Y \& Kishi K (1997) The placenta is not the main source of leptin production in pregnant rat: gestational profile of leptin in plasma and adipose tissue. Biochem Biophys Res Commun 240, 798-802.

Koistinen HA, Koivisto VA, Andersson S, et al. (1997) Leptin concentration in cord blood correlates with intrauterine growth. J Clin Endocrinol Metab 82, 3328-3330.

Korhonen H \& Niemälä P (1998) Effect of ad libitum and restrictive feeding on seasonal weight changes in captive minks (Mustela vison). J Anim Physiol Anim Nutr 79, 269-280.

Leonhardt U, Gerdes E, Ritzel U, Schäfer G, Becker W \& Ramadori G (1999) Immunoreactive leptin and leptin mRNA expression are increased in rat hypo- but not hyperthyroidism. $J$ Endocrinol 163, 115-121.

Littell RC, Milliken GA, Stroup WW \& Wolfinger RD (1996) SAS ${ }^{\circledR}$ System for Mixed Models. Cary, NC: SAS Institute, Inc.

McNeill DM, Slepetis R, Erhardt RA, Smith DM \& Bell AW (1997) Protein requirement of sheep in late pregnancy: partitioning of nitrogen between gravid uterus and maternal tissues. J Anim Sci 75, 809-816.

Masuzaki H, Ogawa Y, Sagawa N, et al. (1997) Non-adipose tissue production of leptin: leptin as a novel placenta-derived hormone in humans. Nature Med 3, 1029-1033.

Morrison CD, Wood R, McFadin EL, Whitley NC, Keisler DH (2002) Effect of intravenous infusion of recombinant ovine leptin on feed intake and serum concentrations of GH, LH, insulin, IGF-1, cortisol and thyroxine in growing prepubertal ewe lambs. Dom Anim Endocrinol 22, 103-122.

Mostyn A, Keisler DH, Webb R, Stephenson T, Symonds ME (2001) The role of leptin in the transition from fetus to neonate. Proc Nutr Soc 60, 187-194. 
Murphy B \& Douglas D (1992) Reproduction in female mink In Reproduction in Carnivorous Fur Bearing Animals. NJF-Utredning/Rapport no. 75, pp. 39-49 [A-H Tauson and M Valtonen, editors]. Copenhagen: Jordbrugsforlaget.

Nagatani S, Zeng Y, Keisler DH, Foster DL \& Jaffe CA (2000) Leptin regulates pulsatile luteinizing hormone and growth hormone secretion in the sheep. Endocrinology 141, 3965-3975.

Naismith DJ \& Morgan BLG (1976) The biphasic nature of protein metabolism during pregnancy in the rat. Br J Nutr 36, 563-566.

Nes N, Einarsson EJ \& Lohi O (1987) Beautiful Fur Animals and their Colour Genetics. Hillerød, Denmark: Scientifur.

Papke RL, Concannon PW, Travis HF \& Hansel W (1980) Control of luteal function and implantation in the mink by prolactin. J Anim Sci 50, 1102-1107.

Pine AP, Jessop NS \& Oldham JD (1994) Maternal protein reserves and their influence on lactational performance in rats. Br J Nutr 71, 13-27.

SAS Institute, Inc. (1990) SAS Procedures Guide, version 6, third ed., Cary, NC: SAS Institute, Inc.

Schubring C, Englaro P, Siebler T, et al. (1998) Longitudinal analysis of maternal serum leptin levels during pregnancy, at birth and up to six weeks after birth: relation to body mass index, skinfolds, sex steroids and umbilical cord blood leptin levels. Horm Res 50, 276-283.

Schwartz MW, Woods SC, Porte D, Seeley RJ \& Baskin DG (2000) Central nervous system control of food intake. Nature 404, 661-671.

Señarís R, Garcia-Caballero T, Casabiell X, et al. (1997) Synthesis of leptin in human placenta. Endocrinology 138, 4501-4504.

Sivan E, Whittaker PG, Sinha D, et al. (1998) Leptin in human pregnancy: the relationship with gestational hormones. Am J Obst Gynecol 179, 1128-1132.

Tauson A-H (1991) Effect of flushing on plasma progesterone and plasma estradiol throughout gestation in mink. J Anim Physiol Anim Nutr 66, 100-110.

Tauson A-H (1993) Effect of body condition and dietary energy supply on reproductive processes in the female mink (Mustela vison). J Reprod Fert 47, Suppl., 37-45.

Tauson A-H (1994) Postnatal development in mink kits. Acta Agric Scand 44A, 177-184

Tauson A-H (1997) Prolactin profiles of pregnant, lactating and non-mated female mink (Mustela vison). J Reprod Fert 51, Suppl., 195-201.

Tauson A-H, Chwalibog A, Fink R, Valtonen M \& Wamberg S (1999) A proposed model for studies on regulation of food intake in a seasonal breeder, the mink (Mustela vison). In Regulation of Feed Intake, pp. 109-113 [D Van der Heide, EA Huisman, E Kanis, JWM Osse and MWA Verstegen, editors]. Wallingford, Oxon: CABI Publishing.

Tauson A-H, Elnif J \& Hansen NE (1991) Energy metabolism and foetal growth in the pregnant mink (Mustela vison). Norw J Agric Sci 9, Suppl., 261-267.

Tauson A-H, Elnif J \& Hansen NE (1994) Energy metabolism and nutrient oxidation in the pregnant mink (Mustela vison) as a model for other carnivores. J Nutr 124, 2609S-2613S.

Tauson A-H, Fink R, Forsberg M, Lagerkvist G \& Wamberg S (2000) LH release in mink (Mustela vison). Pattern of the LH surge and effect of metabolic status. Reprod Nutr Dev 40, 229-247.

Tauson A-H \& Forsberg M (2002) Body-weight changes are clearly reflected in plasma concentrations of leptin in female mink (Mustela vison). Br J Nutr 87, 101-105.

Theil PK, Jørgensen H \& Jakobsen K (2002) Energy and protein metabolism in pregnant sows fed two levels of dietary protein. J Anim Physiol Anim Nutr 86, 399-413.

Thomas L, Wallace JM, Aitken RP, Mercer JG, Trayhurn P \& Haggard N (2001) Circulating leptin during ovine pregnancy in relation to maternal nutrition, body composition and pregnancy outcome. J Endocrinol 169, 465-476.

Tomimatsu T, Yamaguchi M, Murakami T, et al. (1997) Increase of mouse leptin production by adipose tissue after midpregnancy: gestational profile of serum leptin concentration. Biochem Biophys Res Commun 240, 213-215.

Wang J-L, Chinookoswong N, Yin S \& Shi Z-Q (2000) Calorigenic actions of leptin are additive to, but not dependent on those of thyroid hormones. Am J Physiol 279, E1278-E1285.

Woodside B, Abizaid A \& Walker C-D (2000) Changes in leptin levels during lactation: implications for lactational hyperphagia and anovulation. Horm Behav 37, 353-365.

Xiao Y, Forsberg M, Laitinen JT \& Valtonen M (1995) Effects of melatonin implants in spring on testicular regression and moulting in adult male raccoon dogs (Nyctereutes procynoides). J Reprod Fert 105, 9-15.

Zhang Y, Proenca R, Maffei M, Barone M, Leopold L \& Friedman JM (1994) Positional cloning of the mouse obese gene and its human homologue. Nature 372, 425-432. 